ISSN: 2528-4002 (media online)

ISSN: 2355-892X (print)

Online: http://e-journal.sari-mutiara.ac.id/index.php/KesehatanMasyarakat

DOI: https://doi.org/10.51544/jkmlh.v6i1.1918

\title{
FAKTOR-FAKTOR YANG MEMPENGARUHI PERILAKU PEMERIKSAAN IVA TEST PADA WANITA USIA SUBUR DI DESA SIMATUPANG KECAMATAN MUARA TAHUN 2019
}

\author{
Marni Siregar ${ }^{1}$, Hetty WA Panggabean ${ }^{2}$, Juana Linda Simbolon ${ }^{3}$ \\ 1,2,3 Poltekes Kemenkes Medan \\ Jl. Jamin Ginting KM 13,5 Kel Lau Cih Kecamatan Medan Tuntungan \\ marnisiregar63@gmail.com, hettypanggabean54@gmail.com, simbolonjuana@gmail.com
}

Received: Januari 2021; Accepted: April 2021; Published: Juni 2021

\begin{abstract}
ABSTRAK
Kanker serviks adalah kanker paling sering keempat pada wanita dengan perkiraan 570.000 kasus baru pada tahun 2018 dan mewakili 6,6\% dari semua kanker pada wanita. Sekitar 90\% kematian akibat kanker serviks terjadi di negara-negara berpenghasilan rendah dan menengah. Di Indonesia diperkirakan setiap hari muncul 40-45 kasus baru, 20-25 orang meninggal, berarti setiap 1 jam diperkirakan 1 orang perempuan meninggal dunia karena kanker serviks.Indonesia akan kehilangan 600-750 orang perempuan yang masih produktif setiap bulannya. Kurangnya pengetahuan wanita tentang kanker serviks menyebabkan keterlambatan dalam diagnosis sehingga pasien datang dalam kondisi kanker sudah stadium lanjut, keadaan umum yang lemah. Jumlah Cakupan Pelayanan IVA Test Pada WUS Di Wilayah Kerja Puskesmas Muara Tahun 2019 masih rendah yaitu, Desa Untemungkur (9\%), Desa Hutanagodang(8\%), Desa Silalitoruan (5\%), Desa Bariba Niaek (6\%), Desa Simatupang ( 6\%) dan Desa Aritonang (4\%).Jenis penelitian menggunakan pendekatan kuantitatif, dengan rancangan penelitian cross sectional.Populasi seluruh WUS (usia 15-49 tahun) yang berdomisili di Desa Simatupang sebanyak 79 orang, dan yang menjadi sampel adalah yang memenuhi kriteria inklusi dan eksklusi sebanyak 64 orang. Analisis data menggunakan uji statistik chi-square dengan derajat kepercayaan 95\% $(\alpha=$ 0,05). Dari hasil analisis data diperoleh tidak ada hubungan usia dengan perilaku pemeriksaan IVA Test; $\rho=0,637$ ( $p>0,05)$, ada hubungan pendidikan dengan perilaku pemeriksaan IVA Test; $\rho=0,003(p<0,05)$, tidak ada hubungan paritas dengan perilaku pemeriksaan IVA Test; $\rho=0,220$ ( $p>0,05$ ), ada hubungan pengetahuan dengan perilaku pemeriksaan IVA Test; $\rho=0,002(p<0,05)$, ada hubungan sikap dengan perilaku pemeriksaan IVA Test; $\rho=0,000(p<0,05)$. Analisis multivariat regresi logistik diperoleh variabel pendidikan, dukungan kader, dan sikap berhubungan dengan perilaku pemeriksaan IVA Test dengan probabilitas lebih kecil dari nilai ( $p<0,05)$, yaitu masing - masing pendidikan (0,035), dukungan kader (0,026), dan sikap (0,007) yang artinya ada hubungan yang signifikan antara pendidikan dengan perilaku WUS dalam pemeriksaan IVA. Disarankan kepada Pemerintah,Tenaga kesehatan hendaknya meningkatkan penyediaan informasi yang lengkap dan benar mengenai deteksi dini kanker serviks, meningkatkan pembekalan kepada kader tentang deteksi dini kanker serviks, melakukan penyuluhan tentang kanker serviks didesa-desa sehingga Wanita Usia subur lebih rutin melakukan deteksi dini kanker serviks.
\end{abstract}

Kata Kunci : Perilaku, Iva test, Kanker cervic

\section{PENDAHULUAN}

Hingga saat ini kanker serviks masih merupakan masalah kesehatan perempuan di Indonesia sehubungan dengan angka kejadian dan angka kematiannya yang tinggi. Keterlambatan diagnosis pada stadium lanjut, keadaan umum yang lemah, status social ekonomi yang rendah, keterbatasan sumber daya, keterbatasan sarana dan prasarana, jenis histopatologi, dan derajat pendidikan ikut serta dalam menuntukan prognosis dari penderita.

Kanker serviks atau kanker leher rahim adalah jenis tumor ganas yangmengenai lapisan permukaan (epitel) dan leher rahim atau mulut 


\section{ISSN: 2528-4002 (media online)}

\section{ISSN: 2355-892X (print)}

Online: http://e-journal.sari-mutiara.ac.id/index.php/KesehatanMasyarakat

DOI: https://doi.org/10.51544/jkmlh.v6i1.1918

rahim. Penyebab dari kanker serviks adalah infeksi dari Human Vapiloma Virus(HPV). HPV ditularkan melalui hubungan seksual dan ditemukan pada 95\% kasus kanker serviks.

Selain itu, penyebabmeningkatnya kejadian kanker serviks adalah karena kurangnya programpenapisan yang efektif dengan tujuan untuk mendeteksi keadaan sebelumkanker maupun kanker pada stadium dini termasuk pengobatannya sebelumproses invasif yang lebih lanjut. Melalui kegiatan ini diharapkan kesadaran dan kepedulian masyarakat terutama dalam mengendalikan faktor risiko kanker dan deteksi dini kanker sehingga diharapkan angka kesakitan, kematian, akibat penyakit kanker dapat ditekan. Kegiatan ini merupakan bagian dalam mewujudkan masyarakat hidup sehat dan berkualitas, hal ini sesuai dengan tercapainya Nawacita kelima yaitu meningkatkan kualitas hidup manusia.

Pencegahan kanker serviks yang paling efektif adalah melalui pendeteksian dini dengan pap smear atau dengan Inspeksi Visual Asam Asetat Test (IVA Test). Metode IVA Test merupakan salah satu metode yang efektif dan efisien untuk mendeteksi dini kanker serviks, selain dari biaya yang murah juga dapat dilakukan oleh bidan atau petugas Puskesmas. Metode IVA Test sudah dikenalkan sejak 1925 oleh Hans Hinselman dari Jerman, tetapi baru diterapkan sekitar tahun 2005. Skrining dengan metode IVA Test dilakukan dengan cara sangat sederhana, murah, nyaman praktis, dan mudah. Sederhana, yaitu dengan hanya mengoleskan asam asetat (cuka) 3-5\% pada leher rahim lalu mengamati perubahannya, dimana lesi prakanker dapat terdeteksi bila terlihat bercak putih pada leher rahim. Murah biayanya, nyaman karena prosedurnya tidak rumit, tidak memerlukan persiapan, dan tidak menyakitkan. Praktis, artinya dapatdilakukan dimana saja, tidak memerlukan fasilitas laboratorium, cukup tempat tidur sederhana yang representatif, spekulum dan lampu. mudah, karena dapat dilakukan oleh bidan dan perawat yang terlatih,juga memiliki keakuratan sangat tinggi dalam mendeteksi lesi atau luka pra kanker, yaitu mencapai 90 persen.

Sampai tahun 2014, program deteksi dini kanker leher rahim telah berjalan pada 1.986 Puskesmas di 304 kabupaten/kota yang berada di 34 provinsi di Indonesia. Pelatih (trainer) deteksi dini berjumlah 430 orang terdiri dari dokter spesialis obstetri dan ginekologi subspesialis onkologi, dokter bedah, dokter umum dan bidan. Sedangkan pelaksana (provider) deteksi dini di Puskesmas berjumlah 4.127 orang, yang terdiri dari 2.671 bidan dan 1.456 dokter umum. Sedangkan untuk cakupan dan hasil, skrining telah dilakukan terhadap 904.099 orang $(2,45 \%)$, hasil IVA positif sebanyak 44.654 orang $(4,94 \%)$, suspek kanker leher rahim sebanyak 1.056 orang atau 1,2 per 1.000 orang.

Cakupan skrining deteksi dini kanker serviks melalui pemeriksaan IVA Test masih sangat rendah yaitu sekitar 5\%. Padahal cakupan skrining yang efektif dalam menurunkan angka kesakitan dan angka kematian karena kanker serviks adalah $85 \%$. Pengetahuan tentang metode IVA Test sebagai deteksi dini kanker serviks penting agar memiliki kemauan dan kesadaran untuk melakukan IVA Test. Menurut Samadi dalam Riksani, Ria (2016) bahwa jumlah pelaksanaan skrining yang ideal adalah $80 \%$ dari populasi wanita yang ada dalam suatu kawasan. Berdasarkan teori Lawrence green (1980) dalam Thamaria (2016), faktor perilaku ditentukan atau dibentuk oleh faktor predisposisi, yang terwujud dalam pengetahuan, sikap, kepercayaan, keyakinan, nilai-nilai dan sebagainya; faktor pendukung, yang terwujud dalam lingkungan fisik, tersedia atau tidak tersedianya fasilitas-fasilitas atau sarana-sarana kesehatan, misalnya Puskesmas, obat-obatan, alatalat steril dan sebagainya; faktor pendorong,yang terwujud dalam sikap dan perilaku petugas kesehatan atau petugas lain, yang merupakan kelompok referensi dari perilaku masyarakat.

Pendidikan adalah salah satu faktor yang sangat mempengaruhi perilaku masyarakat. Semakin tinggi tingkat pendidikan seseorang semakin mudah orang tersebut menerima informasi sehingga makin banyak pengetahuan yang dimiliki. Mereka akan mengerti dan memahami akan pentingnya melakukan pemeriksaan IVA Test dan sebaliknya apabila pendidikan masyarakat rendah maka makin sedikit pengetahuan yang dimiliki, 
Jurnal Kesehatan Masyarakat dan Lingkungan Hidup

ISSN: 2528-4002 (media online)

ISSN: 2355-892X (print)

Online: http://e-journal.sari-mutiara.ac.id/index.php/KesehatanMasyarakat

DOI: https://doi.org/10.51544/jkmlh.v6i1.1918

sehingga mereka akan mengabaikan dan tidak mengerti akan pentingnya pelayanan kesehatan khususnya pada pemeriksaan IVA Test. Pengetahuan tentang metode IVA Test sebagai deteksi dini kanker serviks penting ntuk dimiliki oleh setiap wanita usia subur agar memiliki kemauan dan kesadaran ntuk melakukan tes IVA Test.

Berdasarkan Profil Dinas Kesehatan Provinsi Sumatera Utara menjelaskan bahwa tahun 2018 sudah dilakukan deteksi dini kanker leher rahim dan payudara terhadap 89.394 perempuan usia $30-50$ tahun $(4,5 \%)$ di Sumatera Utara. Pemeriksaan dilakukan menggunakan metode Pemeriksaan Payudara Klinis (SADANIS) untuk deteksi dini kanker payudara dan pemeriksaan IVA Test atau Pap Smear untuk deteksi dini kanker leher rahim. Cakupan pemeriksaan deteksi dini kanker leher rahim dan payudara pada perempuan usia 30-50 tertinggi terdapat di Kota Tebing Tinggi yaitu sebesar 86,5\%, diikuti oleh Kabupaten Padang Lawas Utarat sebesar 62,5\%, dan Kota Gunungsitoli sebesar 61 ,0\%. Di Kabupaten Tapanuli Utara perempuan usia 30-50 tahun sebanyak 42,644 dengan pemeriksaan leher rahim dan payudara sebanyak 2,576 atau 6,0\% dengan rincian IVA Test positif sebanyak 6 atau $0,2 \%$.

Keterangan yang diperoleh dari Bidan Puskesmas Muara bahwa sosialisasi IVA Test sudah dilakukan baik di puskesmas maupun ke desa - desa. Bidan melakukan sosialisasi dibantu oleh kader yang dilaksanakan pada saatposyandu. Selain itu setiap tahun rutin diadakan pemeriksaan IVA Test masal secara gratis. Di Puskesmas Muara dan di Poskesdes Simatupang juga melayani pemeriksaan IVA Test secara gratis. Akan tetapi jumlah WUS yang mengikuti program tersebut masih rendah.

Jumlah Cakupan Pelayanan IVA Test Pada WUS Di Wilayah Kerja Puskesmas Muara Tahun 2019 yaitu, Desa Untemungkur sebanyak 9\%, Desa Hutanagodang sebanyak $8 \%$, Desa Silalitoruan sebanyak 5\%, Desa Bariba Niaek sebanyak 6\%, Desa Simatupang sebanyak 6\% dan Desa Aritonang sebanyak 4
$\%$.

Studi pendahuluhan telah dilaksanakan di Desa Simatupang pada 10Mei 2019 terhadap 12 WUS. Dari 12 WUS tersebut, didapatkan sebanyak 9 WUS belum pernah melakukan pemeriksaan IVA Test. Terdapat berbagai alasan dari 9 WUS yang belum melakukan pemeriksaan IVA Test, yaitu sebanyak 2 orang mengatakan tidak mengetahui, 5 orang merasa malu, 2 orang merasa takut. Berdasarkan uraian yang telah dipaparkan di atas, peneliti tertarik untuk mengetahui faktor - faktor yang mempengaruhi perilaku pemeriksaan IVA Test pada wanita usia subur di Desa Simatupang Kecamatan Muara Kabupaten Tapanuli Utara tahun 2019.

\section{TUJUAN PENELITIAN}

Tujuan Penelitian ini adalah untuk mengetahui Faktor-faktor apa saja yang mempengaruhi perilaku pemeriksaan IVA Test pada wanita usia subur di Desa Simatupang Kecamatan Muara Kabupaten Tapanuli Utara Tahun 2019

\section{METODE PENELITIAN}

Penelitian ini menggunakan pendekatan kuantitatif, dengan rancangan penelitian cross sectional. Populasi dalam penelitian ini adalah seluruh Wanita usia subur (usia 15 - 49 tahun) yang tinggal di Desa Simatupang sebanyak 79 orang, dan seluruh populasi dijadikan sebagai sample. Adapun kriteria Inklusi adalah sudah pernah menikah, berdomisili di desa Simatupang minimal 6 bulan, bersedia menjadi responden penelitian,sehat jasmani dan rohani, berada di tempat penelitian pada waktu pengambilan data dilakukan, bisa baca tulis, namun yang memenuhi kriteria berjumlah 64 orang yang dijadikan sebagai sampel. Jenis data yang digunakan dalam penelitian ini ialah data primer, yaitu data yang diperoleh langsung dari sumbernya.Teknik pengumpulan data pada penelitian ini adalah melalui penyebaran kuesioner oleh peneliti dan tim secara door to door untuk mendapatkan data usia, pendidikan, pekerjaan, paritas, pengetahuan,sikap, akses informasi, dukungan suami/keluarga, dukungan kaderdan perilakupemeriksaan IVA Test. Data yang terkumpul selanjutnya diproses dan dianalisis $\begin{array}{llll}\text { dengan } & \mathrm{Uji} & \mathrm{Chi} & \end{array}$ 
Online: http://e-journal.sari-mutiara.ac.id/index.php/KesehatanMasyarakat

DOI: https://doi.org/10.51544/jkmlh.v6i1.1918

\section{HASIL}

\section{A. Perilaku Pemeriksaan IVA Test}

Perilaku pemeriksaan IVA Test, faktor pendorong (usia, pendidikan, paritas, pengetahuan, sikap), faktor pemungkin (akses informasi), dan faktor pendorong (dukungan suami/keluarga, dukungan kader).Distribusi dapat dilihat pada tabel 1 berikut ini :

Tabel 4.1 Distribusi Frekuensi Berdasarkan Perilaku Pemeriksaan IVA Test Berupa Faktor Pendukung, Faktor Pemungkin, dan Faktor Pendorong

\begin{tabular}{llll}
\hline No & \multicolumn{1}{c}{ Variabel } & F & \% \\
\hline 1 & ilaku Pemeriksaan IVA & 15 & 23,4 \\
& Periksa & 46,6 \\
ak Periksa & Faktor Pendukung: & & \\
& a. Usia & & \\
& 1) Resiko Rendah & 29 & 45,3 \\
& 2) Resiko Tinggi & 35 & 54,7 \\
& b. Pendidikan & & \\
& 1) Tinggi & 22 & 34,4 \\
& 2) Rendah & 42 & 65,6 \\
& c. Paritas & & \\
& 1) Resiko rendah & 43 & 67,2 \\
& 2) Resiko tinggi & 21 & 32,8 \\
& d. Pengetahuan & & \\
& 1) Baik & 25 & 39,4 \\
2) Kurang & 39 & 60,9 \\
\hline No & $\quad$ Variabel & F & \% \\
\hline
\end{tabular}

e. Sikap

1) Mendukung $\quad 30 \quad 46,9$

2) Tidak mendukung $\quad 34 \quad 53,1$

3 Faktor Pemungkin:

Akses Informasi
1) Baik
27
42,2

2) Kurang

4 Faktor pendorong:

a. Dukungan suami/keluarga

$\begin{array}{lll}\text { 1) Mendukung } & 36 & 56,3 \\ \text { 2) Tidak Mendukung } & 28 & 43,8\end{array}$

b. Dukungan Kader

1) Mendukung $\quad 35 \quad 54,7$

2) Tidak Mendukung $\quad 29 \quad 45,3$

$\begin{array}{lll}\text { Total } & 64 & 100,0\end{array}$


Online: http://e-journal.sari-mutiara.ac.id/index.php/KesehatanMasyarakat

DOI: https://doi.org/10.51544/jkmlh.v6i1.1918

Dari tabel di atas dapat dilihat bahwa dari 64 WUS di Desa Simatupang Kecamatan Muara Tahun 2019 yang tidak melakukan pemeriksaan IVA Test, yakni sebanyak $(76,6 \%)$, berada dalam kelompok usia risiko tinggi yaitu sebanyak $(54,7 \%)$, berpendidikan rendah sebanyak $(65,6 \%)$, memiliki jumlah paritas resiko rendah sebanyak $(67,2 \%)$, memiliki pengetahuan kurang sebanyak $(60,9 \%)$, memiliki sikap yang tidak mendukung pemeriksaan IVA Test sebanyak $(59,4 \%)$, memiliki akses informasi yang kurang baik sebanyak $(53,1 \%)$, mendapatkan dukungan suami/keluarga untuk melakukan pemeriksaan IVA Test sebanyak (56,3\%), dan mendapat dukungan dari kader sebanyak $(54,7 \%)$.

\section{B. Hubungan usia, pendidikan, paritas, pengetahuan, sikap, akses informasi, dukungan suami/keluarga dan dukungan kader dengan perilaku pemeriksaan IVA}

Hubungan usia, pendidikan, paritas, pengetahuan, sikap, akses informasi, dukungan suami/keluarga dan dukungan kader dengan perilaku pemeriksaan IVA istribusi rata-rata dapat dilihat pada tabel 2 berikut ini :

Tabel 4.2. Data Hasil Uji Bivariat Faktor-Faktor Yang Mempengaruhi Perilaku Pemeriksaan IVA Test Pada WUS Di Desa Simatupang Kecamatan Muara

Tahun 2019

\begin{tabular}{|c|c|c|c|c|c|c|c|}
\hline \multirow[t]{3}{*}{ NO } & \multirow[t]{3}{*}{ Variabel } & \multicolumn{4}{|c|}{ Perilaku Pemeriksaan IVA Test } & \multirow[t]{3}{*}{ P value } & \multirow[t]{3}{*}{ PR $(95 \%$ CI $)$} \\
\hline & & \multicolumn{2}{|c|}{ Periksa } & \multicolumn{2}{|c|}{ Tidak Periksa } & & \\
\hline & & $\mathbf{f}$ & $\%$ & f & $\%$ & & \\
\hline \multirow[t]{12}{*}{1} & $\begin{array}{l}\text { Faktor Pendukung } \\
\text { a.Usia }\end{array}$ & & & & & & \\
\hline & $\begin{array}{l}\text { 1) Resiko } \\
\text { Rendah }\end{array}$ & 6 & 20,7 & 3 & 79,3 & 0,637 & $0,805(0,324-1,995)$ \\
\hline & $\begin{array}{l}\text { 2) Resiko Tinggi } \\
\text { a.Pendidikan }\end{array}$ & 9 & 25,7 & 26 & 74,3 & & \\
\hline & 1) Tinggi & 10 & 45,5 & 12 & 54,5 & 0,003 & $3,818(1,489-9,789)$ \\
\hline & $\begin{array}{l}\text { 2) Rendah } \\
\text { b.Paritas }\end{array}$ & 5 & 11,9 & 37 & 88,1 & & \\
\hline & $\begin{array}{l}\text { 1) Resiko } \\
\text { Rendah }\end{array}$ & 8 & 18,6 & 35 & 81,4 & 0,220 & $0,558(0,234-1,332)$ \\
\hline & $\begin{array}{l}\text { 2) Resiko Tinggi } \\
\text { c. Pengetahuan }\end{array}$ & 7 & 33,3 & 14 & 66,7 & & \\
\hline & 1) Baik & 11 & 44,0 & 14 & 56,0 & 0,002 & $4,290(1,534-11,99)$ \\
\hline & 2) Kurang & 4 & 10,3 & 35 & 89,7 & & \\
\hline & d.Sikap & & & & & & \\
\hline & 1) Mendukung & 13 & 43,3 & 17 & 56,7 & 0,000 & $7,367(1,807-30,03)$ \\
\hline & $\begin{array}{l}\text { 2) Tidak } \\
\text { mendukung }\end{array}$ & 2 & 5,9 & 32 & 94,1 & & \\
\hline \multirow[t]{3}{*}{2} & $\begin{array}{l}\text { Faktor pemungkin } \\
\text { Akses Informasi }\end{array}$ & & & & & & \\
\hline & 1) Baik & 12 & 44,4 & 15 & 55,6 & 0,001 & $5,481(1,712-17,55)$ \\
\hline & 2) Kurang & 3 & 8,1 & 34 & 91,9 & & \\
\hline
\end{tabular}


Jurnal Kesehatan Masyarakat dan Lingkungan Hidup

Vol. 6 No. 12021

ISSN: 2528-4002 (media online)

ISSN: 2355-892X (print)

Online: http://e-journal.sari-mutiara.ac.id/index.php/KesehatanMasyarakat

DOI: https://doi.org/10.51544/jkmlh.v6i1.1918

\begin{tabular}{|c|c|c|c|c|c|c|c|}
\hline \multirow[t]{3}{*}{ NO } & \multirow[t]{3}{*}{ Variabel } & \multicolumn{4}{|c|}{ Perilaku Pemeriksaan IVA Test } & \multirow[t]{3}{*}{$P$ value } & \multirow[t]{3}{*}{ PR (95\% CI) } \\
\hline & & \multicolumn{2}{|c|}{ Periksa } & \multicolumn{2}{|c|}{ Tidak Periksa } & & \\
\hline & & $\mathbf{f}$ & $\%$ & $\mathbf{f}$ & $\%$ & & \\
\hline \multirow[t]{6}{*}{3} & $\begin{array}{l}\text { Faktor Pendukung } \\
\text { a. Dukungan } \\
\text { suami/keluarga }\end{array}$ & & & & & & \\
\hline & 1) Mendukung & 10 & 27,8 & 26 & 72,2 & 0,353 & $1,556(0,600-0,404)$ \\
\hline & $\begin{array}{l}\text { 2) Tidak } \\
\text { mendukung }\end{array}$ & 5 & 17,9 & 23 & 82,1 & & \\
\hline & b.Dukungan kader & & & & & & \\
\hline & 1) Mendukung & 14 & 43,8 & 21 & 56,3 & 0,001 & $11,60(1,62-83,03)$ \\
\hline & $\begin{array}{l}\text { 2) Tidak } \\
\text { mendukung }\end{array}$ & 1 & 3,1 & 28 & 96,9 & & \\
\hline
\end{tabular}

Dari tabel 4.2 di atas dapat diketahuidiketahui sebagian besar responden yang tidak melakukan pemeriksaan IVA Test berada pada golongan umur resiko rendah $(79,3 \%)$, pendidikan rendah $(88,1 \%)$, paritas resiko rendah $(81,4 \%)$, berpengetahuan kurang $(89,7 \%)$, bersikap tidak mendukung $(94,1 \%)$, akses informasi yang kurang $(91,9 \%)$, tidak mendapat dukungan dari suami/ keluarga (82,1\%), dan tidak mendapatkan dukungan dari kader sebanyak $(96,9 \%)$.

Hasil analisis hubungan usia dengan perilaku pemeriksaan IVA Test diperoleh nilai $\rho=0,637 \quad(p>0,05)$, yang artinya tidak ada hubungan yang signifikan antara usia dengan perilaku WUS dalam pemeriksaan IVA Test. Hasil analisis hubungan pendidikan dengan perilaku pemeriksaan IVA Test berdasarkan diperoleh nilai $\rho=0,003(p<0,05)$, yang artinya ada hubungan yang signifikan antara pendidikan dengan perilaku WUS dalam pemeriksaan IVA Test. Berdasarkan hasil uji prevalence ratio (PR), didapatkan nilai 3,818 dengan nilai Confidence Interval (CI) 95\% (lower 1,489 dan upper 9,789). Ini artinya ibu yang mempunyai pendidikan rendah, berisiko 3,8 kali lebih besar untuk tidak melakukan pemeriksaan IVA Test dibandingkan dengan ibu yang memiliki pendidikan tinggi.

Hasil analisis hubungan paritas dengan perilaku pemeriksaan IVA Test diperoleh nilai $\rho=0,220 \quad(p>0,05)$, artinya tidak ada hubungan yang signifikan antara paritas dengan perilaku pemeriksaan IVA Test. Hasil analisis hubungan pengetahuan dengan perilaku pemeriksaan IVA Test diperoleh nilai $\rho=0,002(p<0,05)$, yang artinya ada hubungan yang signifikan antara pengetahuan dengan perilaku WUS dalam pemeriksaan IVA Test. Berdasarkan hasil uji PR didapatkan nilai 4,290 dengan nilai Confidence Interval (CI) 95\% (1,534-11,99). Ini artinya ibu yang mempunyai pengetahuan kurang, berisiko 4,29 kali lebih besar untuk tidak melakukan pemeriksaan IVA Test dibandingkan dengan ibu yang memiliki pengetahuan baik. Hasil analisis hubungan sikap dengan perilaku pemeriksaan IVA Test diperoleh nilai $\rho=0,000 \quad(\mathrm{p}<0,05)$, artinya terdapat hubungan yang signifikan antara sikap dengan perilaku WUS dalam pemeriksaan IVA Test.

Berdasarkan hasil uji PR didapatkan nilai 7,367 dengan nilai Confidence Interval (CI) 95\% (1,807-30,036). Ini artinya ibu yang mempunyai sikap tidak mendukung, berisiko 7,367 kali lebih besar untuk tidak melakukan pemeriksaan IVA Test dibandingkan dengan ibu yang memiliki sikap yang mendukung. Hasil analisis hubungan akses informasi dengan perilaku pemeriksaan IVA Test diperoleh nilai $\rho=0,001(p<0,05)$, artinya ada 
Jurnal Kesehatan Masyarakat dan Lingkungan Hidup

Vol. 6 No. 12021

ISSN: 2528-4002 (media online)

ISSN: 2355-892X (print)

Online: http://e-journal.sari-mutiara.ac.id/index.php/KesehatanMasyarakat

DOI: https://doi.org/10.51544/jkmlh.v6i1.1918

hubungan yang signifikan antara akses

informasi dengan perilaku WUS dalam pemeriksaan IVA Test. Berdasarkan hasil uji PR didapatkan nilai 5,481 dengan nilai Confidence Interval (CI) 95\% (1,712-17,553). Ini artinya ibu yang mempunyai akses informasi kurang, berisiko 5,48 kali lebih besar untuk tidak melakukan pemeriksaan IVA Test dibandingkan dengan ibu yang memiliki akses informasi baik.

Hasil analisis hubungan dukungan suami/keluarga dengan perilaku pemeriksaan IVA Test diperoleh nilai $\rho=0,353(\mathrm{p}>0,05)$, artinya secara statistik tidak ada hubungan yang signifikan antara dukungan suami/keluarga dengan perilaku WUS dalam pemeriksaan IVA Test. Hasil analisis hubungan dukungan kader dengan perilaku pemeriksaan IVA diperoleh nilai $\rho=0,001$ $(\mathrm{p}<0,05)$, artinya ada hubungan yang signifikan antara dukungan kader dengan perilaku pemeriksaan IVA Test pada WUS di Desa Simatupang Kecamatan Muara Kabupaten Tapanuli Utara. Berdasarkan hasil uji PR didapatkan nilai 11,6 dengan nilai Confidence Interval (CI) 95\% (1,621-83,026). Ini artinya ibu yang tidak didukung oleh kader, berisiko 11,6 kali lebih besar untuk tidak melakukan pemeriksaan IVA Test dibandingkan dengan ibu yang diberi dukungan oleh kader.

\section{Faktor-faktor yang berhubungan dengan Perilaku Pemeriksaan IVA Test}

Faktor-Faktor yang Berhubungan dengan Perilaku Pemeriksaan IVA Test pada WUS Di Desa Simatupang Kecamatan Muara Tahun 2019 dapat dilihat pada tabel 3 berikut ini : 
Jurnal Kesehatan Masyarakat dan Lingkungan Hidup

ISSN: 2528-4002 (media online)

ISSN: 2355-892X (print)

Online: http://e-journal.sari-mutiara.ac.id/index.php/KesehatanMasyarakat

DOI: https://doi.org/10.51544/jkmlh.v6i1.1918

\section{PEMBAHASAN}

\section{A. Perilaku Pemeriksaan IVA Test}

Dari tabel di atas dapat diketahui Berdasarkan hasil penelitian, menunjukkan bahwa perilaku pemeriksaan IVA Test pada WUS di Desa Simatupang Kecamatan Muara Kabupaten Tapanuli Utara menunjukkan bahwa secaramayoritas tidak melakukan pemeriksaan IVA, yaitu sebanyak (76,6\%). Hal ini sejalan dengan penelitian yang telah dilakukan oleh Nasihah dan Lorna (2013), yang menunjukkan hasil yang tinggi pada ibu yang tidak melaksanakan IVA Test $(83,3 \%)$.

Skrining kanker serviks secara teratur dapat mencegah sebagian besar kanker serviks. Dikarenakan mayoritas kanker serviks terjadi

\section{B. Faktor Pendukung Pemeriksaan IVA Test}

Dari tabel di atas Berdasarkan hasil penelitian, diketahui bahwa tidak terdapat hubungan yang signifikan antara usia dengan perilaku pemeriksaan IVA di Desa Simatupang Kecamatan Muara Kabutapen Tapanuli Utara tahun 2019. Hal ini sesuai dengan penelitian yang telah dilakukan oleh Wahyuni (2013) tentang faktor-faktor yang mempengaruhi perilaku deteksi dini kanker serviks di Kecamatan Ngampel Kabupaten Kendal Jawa Tengah yang menyatakan bahwa tidak ada hubungan yang signifikan antara umur dengan perilaku deteksi dini kanker serviks $(\mathrm{p}=0,540)$, dan penelitian lainnya yang telah dilakukan oleh Gustiana, Dewi, dan Nurchayati (2014) dengan hasil uji korelasi chi square $(p=0,306)$.

Umur tidak dapat dijadikan patokan untuk seseorang melakukan pencegahan kanker serviks. Hal ini dapat disebabkan karena ketidaktahuan, tidak ada keluhan ataupun menganggap pencegahan kanker serviks belum diperlukan.Tidak terdapatnya korelasi antara umur dengan perilaku deteksi dini kanker serviks ini disebabkan terdapatnya persebaran usia yang pada perempuan di negara - negara berkembang, maka penapisan harus efektif dalam mendeteksi perubahan prakanker dan dapat dilakukan di lingkungan dengan sumberdaya yang terbatas. Pemeriksaan IVA Test dapat dipertimbangkan sebagai metode skrining alternative pada lesi leher Rahim karena memiliki berbagai keunggulan seperti sensitifitas dan spesifisitas yang memadai, tidak traumatis, sederhana/praktis dan cepatm dan dapat dikerjakan oleh bidan yang terlatih. Perilaku masih menjadi penghambat pada WUS dalam melakukan deteksi dini kanker serviks. Mengubah perilaku masyarakat terhadap deteksi dini kanker serviks dapat dilakukan dengan pendekatan terhadap perilaku kesehatan, sehingga kegiatannya tidak terlepas dari faktor faktor yang menentukan perilaku tersebut.

hampir sama antara yang beresiko rendah (79,3\%) dan tinggi (74,3\%) dengan perilaku responden yang tidak melakukan pemeriksaan IVA Test. Semakin muda wanita melakukan hubungan seksual maka semakin besar kemungkinan terjadinya kanker serviks. Sehingga, diharapkan untuk sejak dini atau secara rutin untuk melakukan pemeriksaan IVA Test sebagai bentuk upaya deteksi dini terhadap kanker serviks.

Semakin tua seorang wanita maka makin tinggi risikonya terkena kanker serviks. Meskipun begitu, bukan berarti wanita muda tidak dapat terkena kanker serviks. Bahkan, yang memiliki usia muda jika ia tidak memiliki pola hidup yang sehat, maka dapat saja terkena kanker serviks. Pada usia $\geq 35$ tahun wabita mempunyai resiko 15.714 kali untuk terkena kanker serviks dibandingkan dengan wanita yang usia $<35$ tahun.

Berdasarkan hasil penelitian, diketahui bahwa terdapat hubungan yang signifikan antara pendidikan dengan perilaku pemeriksaan IVA Test $(p=0,003)$. Dari hasil uji $P R$ didapatkan nilai 3,818, yang artinya ibu yang mempunyai pendidikan rendah, berisiko 3,8 kali lebih besar untuk tidak melakukan pemeriksaan IVA Test 


\section{ISSN: 2355-892X (print)}

Online: http://e-journal.sari-mutiara.ac.id/index.php/KesehatanMasyarakat

DOI: https://doi.org/10.51544/jkmlh.v6i1.1918

dibandingkan dengan ibu yang memiliki

pendidikan tinggi. Hal ini sejalan dengan penelitian yang telah dilakukan oleh Nasihah tahun 2013 yang menyatakan bahwa terdapat hubungan yang signifikan antara pendidikan dengan cakupan pemeriksaan IVA Test $(p=$ 
Online: http://e-journal.sari-mutiara.ac.id/index.php/KesehatanMasyarakat

DOI: https://doi.org/10.51544/jkmlh.v6i1.1918

0,000), dan penelitian lainnya yang telah dilakukan oleh Rahma dan Prabandari $(p=0,019)$.

Pendidikan memiliki hubungan dengan tingkat pengetahuan seseorang. Pendidikan yang baik akan kesehatan dapat meningkatkan pemahaman masyarakat untuk mencegah penyakit kanker serviks. Semakin tinggi tingkat pendidikan seseorang maka akan meningkatkan pengetahuan dibandingkan dengan mereka yang lebih pendek menempuh pendidikan. Selain itu, menurut Notoatmodjo (2010) menyatakan bahwa pendidikan adalah salah satu faktor yang sangat mempengaruhi perilaku masyarakat.

Sebagian besar responden memiliki pendidikan yang masih rendah (SD dan SMP). Banyaknya jumlah responden yang memiliki pendidikan rendah yang tidak melakukan pemeriksaan IVA Test $(88,1 \%)$ menunjukkan bahwa sebagian besar responden kurang menyadari akan pentingnya pendidikan untuk menjadi jembatan dalam memperoleh informasi.

Tingkat pendidikan yang rendah akan lebih sulit untuk mencerna pesan atau informasi yang disampaikan. Selain itu, pengetahuan sangat erat hubungannya dengan pendidikan, di mana diharapkan bahwa dengan pendidikan yang tinggi maka orang tersebut akan semakin luas pula pengetahuannya. Akan tetapi, perlu ditekankan bukan berarti seseorang yang berpendidikan rendah maka bukan berarti berpengetahuan rendah pula. Hal ini mengingat bahwa peningkatan pengetahuan tidak hanya diperoleh dari pendidikan formal saja, dapat diperoleh dari pendidikan non formal.

Sebagian besar responden memiliki jumlah resiko paritas rendah $(67,2 \%)$. Berdasarkan hasil uji korelasi dengan uji fisher menunjukkan bahwa tidak terdapat hubungan yang signifikan antara paritas dengan perilaku pemeriksaan IVA Test $(p=0,2220)$, dimana sebanyak $81,4 \%$ dari ibu yang memiliki resiko paritas rendah tersebut, memiliki perilaku tidak melakukan pemeriksaan IVA Test sebanyak $81,4 \%$. Hal ini sesuai dengan penelitian yang telah dilakukan oleh Pandey dan Karmacharya (2017) di Nepal yang menyebutkan tidak ada hubungan yang signifikan antara paritas dengan deteksi dini kanker serviks $(p=0,142)$, dilakukan oleh Sherestha, et al., (2012) $(p=0,153)$, dan penelitian lainnya dilakukan di Nigeria oleh Hyacinth, et al., (2013) dengan $p=$ 0,28 . Tidak adanya hubungan yang signifikan antara paritas dengan perilaku pemeriksaan IVA disebabkan karena jumlah responden pada penelitian ini baik yang mempunyai resiko rendah maupun resiko tinggi, sama - sama memiliki persentase yang tinggi terhadap perilaku tidak melakukan pemeriksaan IVA Test. Menurut Pandey dan Karmacharya (2017), meskipun tidak ada hubungan yang signifikan antara paritas dengan perilaku deteksi dini kanker serviks, tetapi dapat dipastikan bahwa semakin tinggi jumlah paritas pada wanita, maka akan semakin tinggi kemungkinan kontak dengan petugas kesehatan, sehingga meningkatkan rekomendasi dalam deteksi dini kanker serviks.Melva (2008), jumlah kehamilan $>3$ kali merupakan faktor prospektif terhadap kejadian kanker serviks. Kanker serviks banyak ditemukan pada wanita yang melahirkan 3-5 kali. Dengan seorang ibu sering melahirkan dan memiliki banyak anak maka akan menyebabkan hormon selama kehamilan dan dapat menimbulkan perlukaan pasca persalinan berubah menjadi sel kanker. Menurut Tapan (2010), perlukaan pasca persalinan dapat menjadikan awal terjadinya kanker serviks apabila tidak segera ditangani. Bukan hanya perlukaan pasca persalinan yang menyebabkan terjadinya kanker serviks tetapi jarak persalinan yang terlalu dekat juga dapat menyebabkan terjadinya kanker serviks. Oleh sebab itu diharapkan wanita yg memiliki paritas tinggi (> 3) sebaiknya 


\section{ISSN: 2355-892X (print)}

Online: http://e-journal.sari-mutiara.ac.id/index.php/KesehatanMasyarakat

DOI: https://doi.org/10.51544/jkmlh.v6i1.1918 lebih waspada dengan cara melakukan deteksi dini secara rutin, salah satunya dengan cara pemeriksaan IVA TestHasil penelitian menunjukkan ada hubungan yang signifikan antara pengetahuan dengan perilaku pemeriksaan IVA Test $(p=0,002)$. Sebagian besar ibu yang memiliki pengetahuan yag kurang, tidak melakukan pemeriksaan IVA Test (89,7\%). Berdasarkan hasil uji $P R$ didapatkan nilai 4,290, artinya ibu yang mempunyai pengetahuan kurang, berisiko 4,29 kali lebih besar untuk tidak melakukan pemeriksaan IVA dibandingkan dengan ibu yang memiliki pengetahuan baik. Hasil penelitian ini sejalan dengan penelitian yang dilakukan oleh Yuliawati (2012) $(p=0,000$; $P R=2,021)$; Dewi, Suryani, dan Murdani (2017) $(p=0,007$; OR = 28,43), Nasihah dan Lorna (2013) dengan uji chi square ( $p=$ 0,000), dan Mirayashi, Raharjo, dan Wicaksono (2014).

Pengetahuan adalah hasil tahu yang terjadi setelah seseorang mengadakan penginderaan terhadap suatu objek tertentu. ${ }^{31}$ Dalam melakukan perilaku pencegahan, dibutuhkan pengetahuan mengenai faktor resiko yang harus dihindari dan pemeriksaan deteksi dini serta peningkatan asupan nutrisi. Perilaku yang didasari oleh pengetahuan akan lebih bertahan lebih lama daripada yang tidak didasari pengetahuan. Keikutsertaan seseorang dalam mengikuti pemeriksaan IVA Test besar pengaruhnya dipengaruhi oleh tingkat pengetahuan seseorang. Jika seseoarng yang mempunyai tingkat pengetahuan yang baik diharapkan akan timbul minat dan benar-benar melakukan pemeriksaan deteksi dini kanker serviks, khususnya IVA Test. Lebih lanjut Mubarrak (2007) mengemukakan bahwa semakin tinggi tingkat pengetahuan ibu, maka semakin baik kemampuan ibu dalam memahami informasi tentang deteksi dini kanker serviks, sehingga meningkatkan pengetahuannya tentang deteksi dini kanker serviks. Berdasarkan penelitian yang dilakukan oleh Yuliawati (2012), rendahnya tingkat pengetahuan WUS disebabkan karena kurangnya informasi. Hal ini akan berdampak terhadap perilaku WUS dalam pemeriksaan IVA Test. Peningkatan pengetahuan ibu tentang kanker serviks dan pemeriksaan IVA Test sebaiknya dilakukan dengan penyuluhan, aik secara formal (penyuluhan di tempat - tempat pelayanan kesehatan, pelatihan bagi kader kesehatan) dan secara informal (penyuluhan di tempat arisan, pengajian, dasawisma, dan

lainnya), baik oleh petugas kesehatan maupun dari pemerintahan setempat. Menurut Sukamti (2013), pemberian penyuluhan memberi dampak terhadap tingkat pengetahuan dan berpengaruh dalam pengambilan keputusan dalam melakukan pemeriksaan IVA. Meningkatnya pengetahuan dapat mengubah perilaku masyarakat dari yang negatif menjadi positif, selain itu pengetahuan juga dapat membentuk kepercayaan.

Berdasarkan hasil penelitian, diketahui bahwa ada hubungan yang signifikan antara sikap dengan perilaku pemeriksaan IVA Test pada WUS di Desa Simatupang Kecamatan Muara Kabutapen Tapanuli Utara tahun 2019 diperoleh nilai $\rho=0,000$; PR = 7,367 . Ini artinya ibu yang mempunyai sikap tidak mendukung, berisiko 7,367 kali lebih besar untuk tidak melakukan pemeriksaan IVA Test dibandingkan dengan ibu yang memiliki sikap yang mendukung. Hal ini sejalan dengan penelitian Yuliawati (2012) $(p=0,000 ; P R=1,813)$; Dewi, Suryani, dan Murdani (2017) $(p=0,014$; OR = $28,77)$; dan Masturoh (2016) ( $p=0,005)$. Sebagian besar ibu yang memiliki sikap yang tidak mendukung, tidak melakukan pemeriksaan IVA Test $(94,1 \%)$. Hal ini sejalan dengan penelitian lain yang menunjukkan bahwa WUS yang memiliki sikap kurang, sebanyak 95,5\% tidak melakukan pemeriksaan IVA Test. Sikap adalah reaksi atau respon seseorang yang masih tertutup terhadap suatu stimulasi atau objek. Sikap belum merupakan tindakan atau aktivitas, melainkan suatu predisposisi perilaku. Penerimaan perilaku baru akan lebih mudah jika didasari oleh pengetahua yang benar, kesadaran, dan sikap yang positif. Sikap pada 


\section{ISSN: 2355-892X (print)}

Online: http://e-journal.sari-mutiara.ac.id/index.php/KesehatanMasyarakat

DOI: https://doi.org/10.51544/jkmlh.v6i1.1918 awalnya diartikan sebagai suatu syarat munculnya suatu tindakan. Fenomena sikap adalah mekanisme mental yang mengevaluasi, membentuk pandangan, mewarnai perasaan, dan akan menentukan kecenderungan perilaku terhadap sesuatu yang kita hadapi. Pandangan dan perasaan terpengaruh oleh ingatan masa lalu, oleh apa yang kita ketahui dan kesan kita terhadap apa yang sedang kita hadapi saat ini. Pada penelitian ini, responden yang memiliki sikap tidak mendukung terhadap deteksi dini kanker serviks adalah sebanyak 53,1\%. Beberapa alasan yang membentuk sikap negatif adalah, menganggap tidak penting, tidak ada resiko kanker serviks, tidak ada tanda gejala yang dicemaskan, takut rasa sakit, malu, takut dengan hasil abnormal, perkiraan penggunaan biaya pemeriksaan, dan takut tidak hieginis. Sikap baik pada responden disebabkan adanya kesadaran bahwa kanker serviks perlu dideteksi dari awal sehingga tidak terjadi keterlambatan dalam pengobatan. Tindakan pencegahan dan deteksi penyakit didasarkan pada keyakinan kesehatan yang dirasakan, antara lain anggapan kesehatan yang dirasakan terhadap ancaman, manfaat, dan hambatan. Menurut Priyaswati, Puspitaningrum, dan Ramawati (2014), sikap yang mendukung tersebut juga dimungkinkan karena adanya motivasi, sikap keingintauannya yang besar dan dorongan dari keluarga.Sikap mendukung atau positif tentang pencegahan kanker leher rahim juga didukung oleh kesadaran diri sendiri dalam upaya mengantisipasi kemungkinankemungkinan yang tidak diinginkan, yang bisa menuju kearah patologis atau komplikasi terhadap akibat kanker leher rahim tersebut.

Pengaruh orang lain dapat mempengaruhi sikap seseorang. Seperti misalnya petugas kesehatan yang memberikan pendidikan kesehatan kepada wanita usia subur sebagai deteksi dini kanker serviks, sehingga meningkatkan ilmu pengetahuan bagi wanita usia subur sehingga akan mempengaruhi sikap wanita usia subur untuk melakukan deteksi dini kanker serviks dengan metode IVA Test, individu cenderung untuk memiliki sikap yang konformis atau searah dengan pemikiran orang lain yang dianggap penting tersebut. Selain itu lingkungan juga dapat berpengaruh terhadap sikap seseorang dalam menerima informasi. Sikap merupakan penentu penting dalam tingkah laku. Sikap yang ada pada diri seseorang akan memberikan gambaran tingkah laku seseorang. Seseorang akan dapat menduga bagaimana respon atau tindakan yang akan diambil oleh orang berdasarkan masalah atau keadaan yang dihadapinya.

\section{Faktor Pemungkin Perilaku Pemeriksaan IVA Test}

\section{a. Akses Informasi}

Berdasarkan hasil penelitian, diketahui bahwa terdapat hubungan yang signifikan antara akses informasi dengan perilaku pemeriksaan IVA Test diperoleh nilai $\rho=0,001(\mathrm{p}<0,05)$. Berdasarkan hasil uji $P R$ didapatkan nilai ibu yang mempunyai akses informasi kurang, berisiko 5,48 kali lebih besar untuk tidak melakukan pemeriksaan IVA Test dibandingkan dengan ibu yang memiliki akses informasi baik. Hasil penelitian menunjukkan responden yang memiliki akses informasi kurang sebanyak $57,8 \%$, dimana sebagian besar ibu yang memiliki akses informasi yang kurang, tidak melakukan pemeriksaan IVA Test $(91,9 \%)$. Hal ini sejalan dengan penelitian yang dilakukan oleh Masturoh (2016) dimana akses informasi mempengaruhi perilaku WUS dalam pemeriksaan IVA Test $(p=0,029)$, dan penelitian lainnya yang telah dilakukan oleh Parapat dan Setyawan (2016) $(p=0,01)$, serta Dewi (2014) ( $p=0,013)$.Penelitian Octavia (2009) menunjukkan bahwa rendahnya partisipasi masyarakat dalam melakukan tindakan pemeriksaan pap smear di Indonesia banyak disebabkan oleh kurangnya tingkat kewaspadaan masyarakat terhadap kanker serviks serta informasi mengenai cara pencegahan dan deteksi dininya.Selain itu, kurangnya pengetahuan akan mempengaruhi ibu untuk tidak melakukan pemeriksaan IVA Test, yang dimungkinkan karena 


\section{ISSN: 2355-892X (print)}

Online: http://e-journal.sari-mutiara.ac.id/index.php/KesehatanMasyarakat

DOI: https://doi.org/10.51544/jkmlh.v6i1.1918

kurang mendapat informasi. Seseorang yang menjalani pemeriksaan IVA Test mendapatkan informasi mengenai kanker serviks dari petugas kesehatan, teman, media elektronik, media cetak, dan keluarga. Informasi dapat diterima melalui petugas langsung dalam bentuk penyuluhan, pendidikan kesehatan, dari perangkat desa melalui siaran dikelompok-kelompok dasawisma atau yang lain, melalui media massa, leaflet, siaran televisi, dan lainnya. Masyarakat lebih mudah menerima informasi melalui media massa, seseorang yang tidak dapat membaca dia dapat mendengar atau mendapat informasi dari televisi, radio dan perkumpulan sehari-hari, sehingga dapat menerima informasi atau pesan-pesan kesehatan yang mengubah pemikiran dan persepsi mereka untuk meningkatkan derajat kesehatan yang lebih baik.

Sebagian besar ibu yang mendapatkan informasi mengenai kanker serviks dari petugas kesehatan lebih cenderung mengikuti deteksi dini kanker serviks. Menurut Reis, et al (2012), petugas kesehatan merupakan salah satu faktor pendorong individu untuk berperilaku. Hal ini dikarenakan petugas kesehatan tersebut ahli dibidangnya sehingga dijadikan tempat untuk bertanya dan memberikan informasi kesehatan yang akurat. Penyampaian informasi yang baik antara petugas kesehatan dengan masyarakat dapat memberikan kontribusi yang positif terhadap perilaku kesehatan yaitu deteksi dini kanker serviks.

\section{Faktor Pendukung Pemeriksaan IVA Test}

1. Dukungan Suami/Keluarga

Berdasarkan hasil penelitian, diketahui bahwa tidak terdapat hubungan antara dukungan suami/keluarga dengan perilaku pemeriksaan IVA Test pada WUS di Desa Simatupang Kecamatan Muara Kabutapen Tapanuli Utara tahun $2019(p=0,353)$. Hasil ini sesuai dengan penelitian Masturoh tahun 2016, yang menyatakan bahwa tidak ada hubungan antara dukungan suami dengan perilaku WUS dalam pemeriksaan IVA Test di Puskesmas Bangetayu Kota Semarang $(p=0,222)$. Berdasarkan hasil penelitian diketahui sebanyak 26 $(72,2 \%)$ ibu yang mendapat dukungan dari suami/keluarga tidak melakukan pemeriksaan IVA Test, sedangkan sebanyak 23 responden yang tidak mendapat dukungan suami/keluarga tidak melakukan pemeriksaan IVA Test adalah sebanyak $82,1 \%$. Hal ini dapat diartikan bahwa belum tentu WUS dengan dukungan suami mendukung melakukan pemeriksaan IVA Test.

Hasil penelitian menunjukkan bahwa ibu yang mendapat dukungan suami/keluarga memiliki persentase lebih tinggi, yaitu sebanyak 56,3\% dibandingkan dengan ibu yang tidak mendapat dukungan suami/keluarga (43,8\%). Responden yang mendapatkan dukungan dari keluarga yang baik akan lebih besar kemungkinan untuk melakukan pemeriksaan IVA Test. Hal ini disebabkan adanya pengaruh yang kuat dari orang terdekat atau suami akan cenderung membuat responden lebih termotivasi meningkatkan taraf kesehatannya. Selain itu, peran suami sebagai pengambil keputusan akan sangat mempengaruhi perilaku WUS tersebut dalam melakukan pemeriksaan IVA Test. Sedangkan responden yang mendapatkan dukungan dari keluarga yang kurang baik akan lebih kecil kemungkinan untuk melakukan pemeriksaan IVA Test. Menurut Sarini (2011), jika seseorang wanita tidak memiliki orang atau kelompok terdekat yang memiliki pemahaman yang baik mengenai kesehatan, maka secara tidak langsung akan berdampak pada perilaku wanita tersebut. Peran suami dan keluarga sangat kuat dalam memberikan dukungan bagi ibu untuk melakukan pemeriksaan kesehatan sehingga akan mempengaruhi status kesehatannya.Menurut Gustiana (2014), menyebutkan bahwa bentuk dukungan dapat berupa dukungan emosional, dukungan penghargaan, dukungan instrumental, dukungan informasi dan dukungan kelompok. 


\section{ISSN: 2355-892X (print)}

Online: http://e-journal.sari-mutiara.ac.id/index.php/KesehatanMasyarakat

DOI: https://doi.org/10.51544/jkmlh.v6i1.1918

2. Dukungan Kader

Berdasarkan hasil penelitian, diketahui bahwa terdapat hubungan yang signifikan antara dukungan kader dengan perilaku pemeriksaan IVA Test pada WUS di Desa Simatupang Kecamatan Muara Kabutapen Tapanuli Utara tahun 2019 ( $p=0,001)$. Dukungan kader juga merupakan faktor yang paling berpengaruh pada perilaku pemeriksaan IVA Test pada WUS di Desa Simatupang Kecamatan Muara Kabutapen Tapanuli Utara tahun $2019(P R=$ 11,6). Hal ini memiliki arti bahwa ibu yang tidak didukung oleh kader, berisiko 11,6 kali lebih besar untuk tidak melakukan pemeriksaan IVA Test dibandingkan dengan ibu yang diberi dukungan oleh kader. Sedangkan berdasarkan hasil multivariat didapatkan bahwa secara bersama-sama probabilitas ibu untuk melakukan pemeriksaan IVA Test bila memiliki pendidikan tinggi, mendapat dukungan kader, dan sikap yang mendukung adalah 22,05\%. Hasil penelitian ini sejalan dengan penelitian Yuliawati tahun 2012 yaitu ada hubungan yang signifikan antara dukungan kader dengan perilaku IVA Test $(p=0,000)$, dan nilai $P R=1,8$ yang berarti WUS yang mendapat dukungan kader lebih berpeluang 1.8 kali lebih besar untuk melakukan pemeriksaan IVA Test dibanding dengan WUS yang tidak mendapat dukungan kader. Hasil penelitian diperoleh ibu yang mendapat dukungan kader yang tidak melakukan pemeriksaan IVA Test sebanyak 21 responden (56,3\%), sedangkan ibu yang tidak mendapat dukungan kader yang tidak melakukan pemeriksaan IVA sebanyak 28 responden (96,9\%). Hal ini sesuai dengan penelitian Susanti (2011) yang menyebutkan bahwa peran kader berhubungan dengan rendahnya kunjungan IVA Test $(p=0,009)$.

Kader Kesehatan adalah perwujudan peran aktif masyarakat dalam pelayanan terpadu. Menurut Dewi (2014) upaya promosi kesehatan mengenai kanker serviks dan deteksi dini kanker serviks oleh tenaga kesehatan dapat dilakukan dengan cara penyampaian pesan melalui kader kesehatan atau penyuluhan di perkumpulan warga seperti saat arisan maupun pengajian. Menurut Susanti (2011), peran kader kesehatan berhubungan dengan rendahnya kunjungan IVA Test, disebabkan kader kesehatan kurang memberikan promosi kesehatan tentang kanker servik dan pentingnya deteksi dini kanker servik dengan IVA Test. Sebagian besar kader kesehatan tidak mencatat siapa saja wanita yang sudah melakukan deteksi dini kanker servik dan kurang mengingatkan wanita yang belum melakukan deteksi dini untuk segera melakukannya. Menurut Dewi, Nurdiamah, dan Achadiyani (2013), kader kesehatan diharapkan dapat membantu menyebarluaskan pengetahuan dan keterampilan yang mereka peroleh kepada masyarakat luas sehingga pengetahuan masyarakat tentang kanker leher rahim dan pencegahannya meningkat.

\section{SARAN}

1. Bagi Pemerintah Kabupaten Tapanuli Utara

Pemerintah hendaknya meningkatkan penyediaan informasi yang lengkap dan benar mengenai deteksi dini kanker serviks, sehingga mudah diakses oleh masyarakat.

2. Tenaga Kesehatan

Diharapkan dapat meningkatkan pembekalan kepada kader tentang deteksi dini kanker serviks, serta melibatkan kader kesehatan untuk melakukan penyuluhan tentang kanker serviks didesa-desa.

3. Masyarakat

Agar lebih rutin melakukan deteksi dini khususnya deteksi dini kanker serviks pada wanita usia subur.

\section{DAFTAR PUSTAKA}

1. Arikunto, S. (2013). Prosedur Penelitian Suatu Pendekatan Praktek. Jakarta: Rineka Cipta.

2. Arini. (2012). Mengapa Seorang Ibu Harus Menyusui. Yogyakarta.: Flash Books. Arum, 


\section{ISSN: 2355-892X (print)}

Online: http://e-journal.sari-mutiara.ac.id/index.php/KesehatanMasyarakat

DOI: https://doi.org/10.51544/jkmlh.v6i1.1918

Pupita Shreia. (2015). Stop Kanker

Serviks. Yogyakarta: Notebook.

3. Azwar, Saifuddin. (2010). Sikap Manusia: Teori dan Pengukurannya. Yogyakarta: Pustaka Pelajar.

4. Basu,Partha,Salma Hasan.et al. (2014). Knowledge,Attitude And Practices Of Women In Maldives Related To The Risk Factors, Prevention And Early Detection Of Cervical Cancer. Diakses Pada Tanggal 23 Agustus 2019 Melalui http://dx.doi.org/10.7314/APJCP.2014.1 $\underline{5.16 .6691 .}$.

5. Baran, Stanley J. (2012). Pengantar Komunikasi. Massa Jilid 1 Edisi 5. Jakarta: Erlangga.

6. Bauman AE, Reis RS, et all. Correlates of physical activity: why are some people physically active and others not? Diakses Pada Tanggal 3 Agustus 2019 Melalui

https://www.ncbi.nlm.nih.gov/pubmed/2 2818938.

7. Depkes RI. (2009). Pencegahan Kanker Leher Rahim Dan Kanker Payudara. Jakarta.

8. Dinas Kesehatan.Direktorat Pengendalian Penyakit Tidak Menular. Buku Saku Pencegahan Kanker Leher Rahim\& Dan Kanker Payudara.Diakese Pada Tanggal 27 September 2019.

9. Fitriani,Sinta. (2011). Promosi Kesehatan.Yogyakarta : Graha Ilmu.

10. Globocan-IARC. (2014). Estimated cancer incidence, mortality and prevalence worldwide in 2012. International Agency for Research on Cancer, World Health Organization. http://globocan.iarc.fr/Pages/fact_sheets _cancer.aspx. [12 Oktober 2019].

11. Gu,Can,et al. (2016). Chinese women's motivation to receive future screening: the role of social-dempgraphic factors,knowledge and risk perception of cervical cancer. European journal of oncology nursing.www.lsevier.con/locate/ejon.diakses pada tanggal 04 Oktober 2019.

12. Hucklock B.E,(2008). Psikologi Perkembangan Suatu Pendekatan Sepenjang Rentang Kehidupan. Jakarta : Erlangga.

13. Kementerian Kesehatan RI Direktort Pengedalian Penyakit Tidak Menular. (2015). Program Nasional Gerakan Pencegahan Dan Deteksi Dini Kanker Leher Rhim Dan Kanker Payudara. Diakses Pada Tanggal 24 September 2019 darihttp://www.pptm.depkes.go.id/cms/fronte d/ebook/Buku_Panduan_Pelaksan aan _IVA_SADANIS_2015.pdf.

14. Komite Penanggulangan Kanker Nasional. (2015). Diakses Pada Tanggal 27 September 2019 Melalui http://kanker.kemkes.go.id/.

15. Kumalasari,Intan. (2012). Kesehatan Reproduksi. Jakarta: Salemba Medika. Kurniwati,Indah. (2015). Pengaruh, Pengetahuan, Motivasi Dan Dukungan Suami Terhadap Perilaku Pemeriksaan IVA Pada Kelompok Wanita Usia Subur Di Puskemas Kedungrejo. Diakses Pada Tanggal 23 September $2019 \quad$ melalui https://digilib.uns.ac.id/.../PengaruhPengetahuan-Motivasi-Dan-Dukungan.

16. Lestari, S, Indah.(2016). Faktor - Faktor Yang Mempengaruhi Kesediaan WUS Dalam Melakukan Deteksi Dini Kanker Serviks Di Puskesmas Menahan Surakarta. FKM UMS. Diakses Pada Tanggal 31 September 2019.

17. Lyimo,S,Frida,Beran N,Tanya.(2012). Demographic, knowledge, attitudinal, and accessibility factors associated with uptake of cervical cancer screening among women in a rural district of Tanzania: Three public policy implications. Diakses Melalui https://www.ncbi.nlm.nih.gov/pmc/articles/P MC3299640/.

18. Luque, S, John.(2016).Social Network Characteristic And Cervical Cancer Screnning Among Quechua Women In Andrean Peru. Diakses Melalui 


\section{ISSN: 2355-892X (print)}

Online: http://e-journal.sari-mutiara.ac.id/index.php/KesehatanMasyarakat

DOI: https://doi.org/10.51544/jkmlh.v6i1.1918

https://www.ncbi.nlm.nih.gov/pmc/articl es/DOI 10.1186/s12889-016-2878-3/.

19. Mahersie,L.(2012). Hubungan Pengetahuan Ibu Tentang Kanker Serviks Dengan Keikutsertaan Ibu Melakukan IVA Di Kelurahan Jebres Surakata. Gaster Jurnal Ilmu Kesehatan, 9(2),46-54.

20. Martini, N,K.(2013).Hubungan Karakteristik,Pengetahuan,Sikap

Dengan Tindakan Pemeriksaan Pap Smear Di Puskesmas Sukawati II. Diakses pada tanggal 27 April 2016. Melalui www.pps.unud.ac.id/pdf_thesis/unud778-265413185- tesis.

21. Mayrita,N,Sisca\&

Handayani,Nanik.(2016) Hubungan Antara Paritas Dengan Kejadian Kanker Serviks Di Yayasan Kanker WisnuWardhana Surabaya. Diakses pada tanggal 07 September 2019 Melalui http://journal.unusa.ac.id/index.php/jhs/.

22. Nursalam. (2008). Metode Penelitian Ilmu Keperawatan.Jakarta: Salemba Medika.

23. .(2011). Metodologi Penelitian

Ilmu Keperawatan. Jakarta: Salemba Medika.

24. Notoatmodjo, Soekidjo.(2012). Promosi Kesehatan dan Perilaku Kesehatan.Edisi Revisi 2012. Jakarta : Rineka Cipta.

25. Notoatmodjo, S. (2010). Metedologi penelitian kesehatan. Jakarta: Rineka Cipta.

26. Orang,O,Elkanah et al.(2016). Factors Associated with Uptake of Visual Inspection with Acetic Acid(VIA) for Cervical Cancer Screeningin Western Kenya.Diakses Pada tanggal 12 September 2019 melalui https : // www .ncbi .nlm .nih .gov/ pubmed /2 7310005 .
27. Purba, Evi Misrawaty.(2011). Faktor- Faktor yang Berhubungan dengan Pemeriksaan Pap Smear Pada Pasangan Usia Subur (PUS) di Puskesmas Belawan Kota Medan Tahun 2011. https : // www .ncbi .nlm .nih .gov/ pubmed /2 731000

28. Rohmawati, Ika.(2011). Faktor- Faktor Yang Berhubungan Dengan Perilaku Wanita Usia Subur Dalam Deteksi Dini Kanker Serviks Dengan Metode IVA Di Wilayah Kerja Puskesmas Ngawen I Kabupaten Gunung Kidul Tahun 2011.FKM UI.Diakses Pada Tanggal 14 Oktober 2019.

29. Sarini,Ni Ketut Manik.(2011). Faktor- Faktor Yang Berhubungan Dengan Pemeriksaan Pap Smear Pada Wanita Usia Subur Didesa PacungWilayah Kerja Puskesmas Tejakula II Kecamatan Tejakula Kabupaten Buleleng Bali.Diakses tanggal 16 Oktober 2019.

30. Setiadi. (2007). Konsep dan Penuisan Riset Keperawatan.Yogyakarta: Graha Ilmu. Sugiyono.(2016). Metode Penelitian Kuantitatif Kualitatif \&RND. Bandung:Alfabeta.

31. Sukaca,E.B.(2009). Cara Cerdas Menghadapi Kanker Serviks (Leher Rahim). Yogyakarta : Genius Printika.

32. Sunaryo. (2014). Psikologi Untuk

Keperawatan. Ed.2.Jakarta: EGC.

33. Susanti, Aris. (2011). Faktor- Faktor Yang Berhubungan Dengan Rendahnya Kunjungan IVA Di Wilayah Kerja Puskesmas Halmahera Kecamatan Semarang Timur.Diakes pada tanggal 23 Oktober 2019.

34. Susilowati E dan Anna Ms. 2013. Pengetahuan Tentang Faktor Resiko, Perilaku dan Deteksi Dini Kanker Serviks dengan Inspeksi Asam Asetat (IVA) pada Wanita di Kecamatan Bogor Tengah Kota Bogor. Buletin Penelitian Kesehatan, 42 (3), September 2014: 193-202 Diakses Pada Tanggal 20 September 2019 Melalui http://ejournal.litbang.depkes.go.id/index.php/ BPK/article/view/3632. 
Jurnal Kesehatan Masyarakat dan Lingkungan Hidup

Vol. 6 No. 12021

ISSN: 2528-4002 (media online)

ISSN: 2355-892X (print)

Online: http://e-journal.sari-mutiara.ac.id/index.php/KesehatanMasyarakat

DOI: https://doi.org/10.51544/jkmlh.v6i1.1918

35. Taringan, L, Frida. (2014). FaktorFaktor yang Berhubungan Dengan Perilaku WUS Dalam Deteksi Dini Kanker Serviks Dikelurahan Dwikora Medan. IKM USMIndonesia. Diakses Pada Tanggal 12 Oktober 2019.

36. Wahidin, M. (2015). Buletin Jendela Data dan Informasi Kesehatan, Situasi Penyakit Kanker. Pusdatin Kemenkes RI.

37. Wahyuni,Sri.(2013). Faktor -Faktor Yang Mempengaruhi Perilaku Deteksi Dini Kanker Serviks Dikecamatan Ngampel Kabupaten Kendal Jawa Tengah. Diakses Melalui http:// http://scholar.google.co.id/. Pada tanggal 18 September 2019.

Peran Dukungan Keluarga Terhadap Pengambilan Keputusan Deteksi Dini Kanker Serviks. Diakses pada tanggal 10 Oktober 2019 melalui http://ww.ejr.stikesmuhkudus.ac.id/index.php/

41. World health Organization. (2018). Cervical Cancer. cancer/prevention/diagnosisscreening/cervicalcancer/en// Diakses Pada Tanggal 27 Oktober 2019 Melalui https://www.kemkes.go.id/resources/downloa d/profil/PROFIL_KES_PROVINSI_2018/02 Sumut_2018.pdf.

42. Yuliwati.(2012). Faktor-Faktor Yang Berhubungan Dengan Perilaku WUS dalam Deteksi Dini Kanker Leher Rahim Metode IVA Di Wilayah Puskesmas Prembun Kabupaten Kebumen.Depok: Fakultas Kesehatan Masyarakat Universitas Indonesia.Diakses Pada tanggal 13 September 2019 melalui

39. Widyanto,F,C.(2014). Keperawatan Komunitas Dengan Pendekatan Praktis. Yogyakarta: Nuha Medika.

40. Wiganti, Atun \& Nisak, Z,Ana.(2017) http://lib.ui.ac.id/file?file=digital/20318324-SYuliwati.pdf 